CLINICAL HEMORHEOLOGY, Vol. 10, page 567, 1990

$0271-5198 / 90 \$ 3.00+.00$ Printed in the USA.

Copyright (c) 1990 Pergamon Press plc. All rights reserved.

\title{
CONTENTS OF BIORHEOLOGY, VOLUME 27, NUMBER 2
}

Contents

Z. Priel and A.C. Tsoi

S. Chien, S.-S. Feng, M. Vayo, L.A. Sung, S. Usami and R. Skalak

I.. Dintenfass

F.N. Van de Vosse, A.A. Van Steenhoven, and J.D. Janssen

L.L. Wickham, R.M. Bauersachs, R.B. Wenby, S. Sowemimo-Coker H.J. Meiselman and R. Elsner

N. Iida

G. Qiong, R.E. Pitt and A. Ruina

M. long, Y. Toyama, T. Dobashi, A. Sakanishi, Y.P. Wu and S. Oka

\section{Papers}

125 On self synchronization-aspects of flagellar and ciliary beating

135 The dynamics of shear disaggregation of red blood cells in a flow channel

149 Blood as a near-"ideal" emulsion: a retrospective on the concept of the red cell as a fluid drop, its implications for the structure of the red cell membrane

163 A two-dimensional numerical analysis of unsteady flow in the carotid artery bifurcation

191 Red cell aggregation and viscoelasticity of blood from seals, swine and man

205 Effects of vasomotion and venous pressure elation on capillary-tissue fluid exchanged across hetero-porous membrane

225 A mechanics model of the compression of cells with finite initial contact area

Brief Communication

241 Effect of electric field on erythrocyte sedimentation rate 1 . Enhancement in saline solution

247 Announcements

253 Contents of CLINICAL. HEMORHEOLOGY, Volume 9, Number 6

I Software Survey Section 